\title{
国立大学の改修プロジェクトにおける省エネ化推進に関する研究 STUDY ON PROMOTING ENERGY SAVING RENOVATION PROJECTS IN THE NATIONAL UNIVERSITIES
}

\author{
藤 村 達雄*, 横尾昇 剛** \\ Tatsuo FUJIMURA and Noriyoshi YOKOO
}

\begin{abstract}
Today, most of national universities have introduced thermal insulation, double-glazing and high efficiency equipment in the renovation projects. It needs to specify issues to enhance energy saving, Following survey and analysis are conducted;

1. Current energy saving strategies are summarized based on the organization of facility planning in the national universities.

2. A questionnaire survey was conducted to the facility planning departments and actual condition were clarified or shown?

3. The hearing regarding energy saving measures to the universities that promoting energy saving measures, specified devised points and problems, and clarified obstructive factors and requirement of energy saving promotion.
\end{abstract}

\author{
Keywords : National university corporation, Energy-saving measures, Design process, Repair project, Design \\ guideline in the study \\ 国立大学法人，省エネ対策，設計プロセス，改修プロジェクト，学内設計指針
}

\section{1.はじめに}

\section{$1-1$ 研究の背景と目的}

地球環境問題は，建築分野においても，環境に配虑した取り組み が急務となっている。個々の建築物においては，建築のライフサイ クルを通し低炭素社会の実現に向けた取組の推進が，建築主・設計 者の社会的な責任として求められている。

しかし，国立大学法人では企画から基本設計までが短期間でまと められ，十分な検討がなされないまま実施設計に着手する傾向があ るとともに，関係者の役割分担が明確になされていない状況がある など設計プロセスの改善が求められている ${ }^{1)}$ 。

国立大学法人全体のエネルギー使用量は約 4,100 万 GJ / 年で, 1 $\mathrm{m}^{2}$ あたりエネルギー使用量は, 文科系が $531 \sim 887 \mathrm{MJ} / \mathrm{m}^{2}$ ・年, 理・ 農学系 $1,242 \sim 1,968 \mathrm{MJ} / \mathrm{m}^{2} \cdot$ 年, 工学系 $1,102 \sim 1,739 \mathrm{MJ} / \mathrm{m}^{2} \cdot$ 年, 医学系 $1,447 \sim 2,223 \mathrm{MJ} / \mathrm{m}^{2} \cdot$ 年, 附属病院 $3,707 \sim 4,876 \mathrm{MJ} / \mathrm{m}^{2} \cdot$ 年と，文科系を 1 とした場合， $1 \mathrm{~m}^{2}$ あたりエネルギー使用量は，1： $2: 2: 2.5: 6$ の比率である ${ }^{2)}$ 。学問系統注 1$)$ による開きは約 6 倍あ る。これまでの大学ではエネルギー使用量の占める割合の高い建築 設備の省エネ対策を進めてきたが, 実験装置の運用改善を含めた省 エネ対策に取り組むことも課題となっている ${ }^{3)}$ 。

また，国立大学等注 2$)$ 施設は平成 27 年 5 月時点で, 2,812 万 $\mathrm{m}^{2}$ 保 有し, 25 年以上経過し大規模改修整備が必要な老朽施設は 846 万 $\mathrm{m}^{2}$

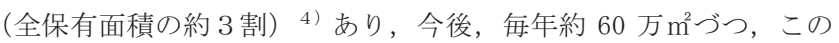
面積は増え続ける状況である。

これらの状況から, 国立大学法人が今後進める既存施設の改修整
備（以下「改修プロジェクト」）においては，運用改善を考慮した省 エネルギー化のための設計プロセスが求められる。本研究では, 施 設整備の仕組みと省エネ化に向けた設計プロセスについての実態把 握と省エネ化のための推進方策を明らかにすることを目的とする。

なお，本研究では，次のように用語を定義する。

・省エネ対策：運用段階における一次エネルギー消費量を削減す るために方針等を示し, 企画から運用までのライフサイクルに亘り， ハードだけでなくソフト（組織・運営）を含めた継続的な対策。

・設計プロセス：各設計過程に必要な設計行為, 設計情報, 設計 体制を明確にし，体系化すること。

・推進方策 : 省エネ対策を取り入れた改修プロジェクト（以下「省 エネ改修プロジェクト」)における施設の質の向上と施設整備業務の 効率化・合理化を図るための工夫や知見。

・学内設計指針：「省エネ対策」と「設計プロセス」に基づき，学 内事情を反映した「推進方策」を整理し，各大学が策定する基準。

\section{1-2 既往の研究}

大学の省エネルギー化については, 河野ら ${ }^{5)}$ が, 大学のエネルギ 一消費実態, 設備導入・稼働実態から学内指針を策定することで, 大学全体の方針を統一寸ることができ, 環境負荷低減のマネジメン 卜論の発展に寄与できる一つの手法を示している。李ら ${ }^{6)}$ は, 九州 大学の移転事業のための環境・省エネルギー計画の基礎的検討の一 つとして，既存キャンパスのエネルギー消費構造，モデル建物によ る外皮計画のシミュレーション等から省エネルギー指針案の知見を 示している。大橋ら ${ }^{7)}$ は, 運用改善がもたら寸省エネルギー効果の 定量化には，照明・空調・換気・コンセントその他の 4 つのエネル
* 宇都宮大学大学院工学研究科 博士後期課程

** 宇都宮大学大学院工学研究科 准教授・博士 (工学) 
ギー消費内訳把握が重要であることを示した。

大学キャンパスの設計プロセスについては, 北尾ら ${ }^{8)}$ が, 建築物 とその外部環境を混在させる集合形態の生成に果たすマスターアー キテクトの役割方法を明らかにできたので, 今後の類似した事例の 分析をできるとしている。事業用建物の設計プロセスについては, 水川ら 9) が, 発注者業務構造モデルの一形式として, 「事業スキー ムの計画」「事業スキーム確証化」「事業スキームの資料化」「事業ス キームのコスト化」という 4 つの段階に構造化できることが明らか になったとしているが, 汎用的構造モデルと判断するのは早計であ るとしている。

しかしながら, 大学の省エネルギー化を設計プロセスの視点から 研究したものと, 国立大学法人の施設整備の仕組みや執行組織を設 計プロセスや省エネルギー化の視点から分析したものはほとんどな い状況である。

\section{2. 国立大学法人の施設整備の仕組みと執行組織の概況}

\section{2-1 国の方針：国立大学法人等施設整備 5 か年計画}

文部科学省（以下「文科省」という）は，平成 13 年度から 4 次に わたり，科学技術基本計画を受けた国立大学法人等施設整備 5 か年 計画を策定し, 計画的・重点的に施設整備を推進している。今期 5 か年計画（平成 28 年度 32 年度）10) では, 進捗が遅れている施設 の老朽対策を踏まえた「安全・安心な教育研究環境の基盤の整備」, これにあわせた「国立大学等の機能強化等変化への対応」注3) と, 省エネルギーや環境負荷の低減に一層貢献できる「サステイナブ ル・キャンパスの形成」の 3 つの課題に取り組む必要があるとして いる。これらの進捗状況を把握するために, 各大学には重要業績評 価指標（以下「KPI」という）を設けることを求めている。

なお，前期 5 か年計画（平成 23 年度〜27 年度）では，基本的考 え方に「Sustainability〜地球環境に配慮した教育研究環境の実現 〜」を掲げ，省エネルギー等の推進を個別目標とし，高効率照明・ 空調設備の導入や断熱材などを含む老朽改善整備事業を平成 27 年 9 月現在 882 事業実施している ${ }^{11}$ 。

\section{2-2 キャンパスマスタープラン}

文科省は, 国立大学法人が教育研究活動と密接不可分の関係にあ るキャンパスを整備・活用し，持続的発展を図るためキャンパス環 境全体の基本的な計画である「キャンパスマスタープラン」（以下 「CMP」という）を策定することを奨励している。文科省の手引き 12) では, (1)キャンパス像に関する長期的ビジョンを確立する, (2)キ ヤンパス環境の質の向上を図る, (3)あるべき姿を示し, 変化の必要 性の周知，(4)施設の配置とデザイン決定の理論を確立するなどを CMP の目的としている。また, この手引きでは, 省エネルギーを法 人の責務として位置づけている。国立大学等の CMP の策定率は平成 27 年 9 月現在, $95.6 \%$ である ${ }^{11}$ 。

\section{$2-3$ 施設整備の財源}

国立大学の施設整備は，国が措置する施設整備費補助金を基本的 財源としながらも，運営費交付金，目的積立金，寄付金，間接経費 等の多様な財源を活用し実施されている。老朽改善のための改修プ ロジェクトは，大部分が施設整備費補助金を財源としている。この 施設整備費補助金は, 毎年各国立大学法人から要望される約 4,000 億円強に対して，国からは500 億円程度が配賦される状況である。
また，施設整備の財源における省エネ化対念については，環境対 策加算として, 従来から認められている断熱材打込, 照明制御等に 加え, 近年, 複層ガラス, 壁面緑化, 風力発電, 地中熱利用, 集中 検針装置等が認められるようになっている ${ }^{13)}$ 。

\section{2-4 施設部署の法人化による変化}

国立大学法人の施設部署は, 平成 16 年度の法人化を契機に, それ までの施設整備主体の業務形態から, 総合的・長期的な視点に立つ た「施設マネジメント」注4) への対応のため ${ }^{14)}$ ，「業務の拡大」が 求められ，施設の管理・運営を取り込む組織に見直すところが出て きた。それは, 従前の建築・電気設備・機械設備の専門毎の組織形 態から，企画・整備・維持保全の業務プロセスの組織形態に改める ものである。また，スムーズな施設の整備や管理運営とキャンパス での実証実験等のために，施設部署が教員との協働関係を築く必要 から，「教職協働」がより求められるようになった。

国立大学法人は法人化後「業務量の増加」というアンケート結果 がある ${ }^{15)}$ 。施設部署においても, 労安法対応業務, 省エネ法に基づ くエネルギー管理業務，中期目標・評価制度への対応業務等が増え た。また, 今後, インフラ長寿命化対応業務が増えてくることが見 込まれている。

\section{$2-5$ 本部と部局}

国立大学法人は, 学部, 附属病院, 研究組織等の部局と, 学長を 支援する本部とからなる。本部には，総務・財務・学務等の事務組 織のなかに，施設関係業務を所掌する部署が，大学の規模に応じて 部や課として設置されている。部局には，大きな大学の場合には独 自に, 同一キャンパス内のいくつかの部局をまとめる場合に共同し て，施設担当者を設置していることもある。本部の施設部署は，施 設担当者のいない部局の維持保全業務等を含めて進めている。

なお，改修プロジェクトにおいて運用改善を取込み，反映した省 エネ対策を進めるには，当該部局の管理部署と教員の協力が久かせ ないが,「伝統的に学部や学科といった組織単位での構成員自治が強 い」16) ことから，組織の縦割り意識に阻まれる場合もある。

\section{$2-6$ 技術的基準等}

国立大学法人では，施設整備に関する基準類は「統一基準」注 5) を原則として使用寸ることになっている。しかし，統一基準に馴染

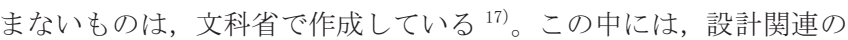
ものとして, 建築構造設計指針, 国立大学等施設設計指針 ${ }^{18)}$ があ る。省エネルギー関係の設計関連のものは, 統一基準の「官庁施設 の環境保全性基準」19) のみである。技術的基準として明確な位置付 けがないが，平成 8 年に作成された電気設備工事設計資料，機械設 備工事設計資料は，現在も実施設計を委託する際に適用基準として 使われている。これらの設計資料は，近年のクールビズ／ウォーム ビズや，東日本大震災による意識変化等の社会情勢を踏まえた改訂 が待たれるところである。「官庁施設の環境保全性基準」は，実施設 計委託の際の適用基準とはされていない。これらのことから，国立 大学法人においては, 省エネに係る技術的基準が不明確であるとい える。

また，文科省では，エネルギーの使用の合理化に関する法律第 6 条に基づく指導・助言の一環として，大学等における省エネルギー 対策の基本的な考え方や推進方策等を, 手引き・事例集としてまと めている ${ }^{20)}$ 。この中には，実験等に伴うエネルギー消費が，大学全 
体の 3 割以上を占める例もあることから, 実験装置等の運用改善に 言及し省エネ対策の必要性などを解説した事例集 ${ }^{21)}$ もるる。

\section{$2-7$ 施設整備プロジェクトの流れ}

一般的な流れ（企画・基本計画 - 基本設計 - 実施設計 ・ 施工） と 並行に, 国立大学法人が行う CMP 等の大学方針の策定, 概算要求書 提出，実施計画案調書，運営支援等を図示した（図 1 )。

各大学から提出された概算要求書は，文科省に設置された「国立 大学法人等施設整備に関する検討会」（以下「施設検討会」）におい て事業評価され，この結果を勘案して文科省が予算の状況を考慮の 上, 事業選定を行う。この事業選定に基づき, 財務省に提出された ものが予算案として作成され, 国会の議決を経て成立する。予算案 が決定され内示を受けた大学は, 実施計画案調書を文科省に提出す る。これとは別に, 補助金交付に係る手続きを経て, 交付が決定さ れ，各大学での具体的な事業が進められることになる。

施設検討会は, 平成 13 年から事業評価・事業選定の透明性・客観 性を確保する観点から学識経験者等の参加により開催されている 22)。事業評価は, 平成 28 年度に大きく見直され, 今期 5 か年計画の 課題「サステイナブルキャンパスの形成」については, 満点 17 点の うち 3 点が配分されている。その評価項目は, 環境対策工事項目数 あるいは, $\mathrm{CO}_{2}$ 削減量が満点 2 点, 先導的モデルの取組が満点 1 点, この 2 つである ${ }^{23)}$ 。各大学は, これを受け概算要求の際に, 断熱材, 複層ガラス, 高効率設備の導入等の環境対策工事項目数あるいはそ れらによる $\mathrm{CO}_{2}$ 排出削減量等や, ZEB 化のための取組等, 先導モデル の計画を示すものを評価資料として提出している。

\section{3. 大学の実態調査等}

\section{$3-1$ 調査概要}

国立大学法人の改修プロジェクトにおける省エネ対策の現状を明 らかにするために，表1のとおりアンケート調查を実施した。

\section{3-2＼cjkstart環境配慮に対する取組}

環境配慮に対する取組については，既存文献1）5）18）24２5）26）に基 づき, 選択肢(1)〜 (9)注6) を掲げ実施しているもの全ての回答を求め, 図 2 の結果を得た。なお，自由記述欄に，(6)の基準の内容や運用状 況，(9)その他の取り組み内容の回答を得た。(1)の割合は $62 \%$ ，(2)が $22 \%$ ，(3)と(4)が 0\%，省エネ目標の設定が十分になされていない状 況である。(6)の基準は，26\%（17 校）で策定しているが，省エネの 仕様・留意事項を提示したものが主で，作成者の異動などにより， 十分に活用されていないと回答を得ている。(9)の 17 校には， $\mathrm{CO}_{2}$ 削 減を目指寸専門組織の設置や，コミッショニングの実施，管理一体 型 ESCO 注7) 等, 環境配慮に係る活動において他大学に比べ進んだ取 組内容が記載されている。

\section{3-3 施設部署の組織形態}

2-4 に記述した国立大学法人後の施設部署に求められる「業 務の拡大」「教職協働」に対応するために組織形態等がどのようにな っているかを確認するためにアンケートした。「業務の拡大」への対 応状況は施設部署を 4 つのタイプに分け，「教職協働」は教員支援夕 イプを 5 つに分け，その回答を，財務規模等による 8 分類注 8$)$ に従 い整理した（表 2 , 図 3，4）。

施設部署のタイプは, 回答機関 65 校のうち, 従来型の専門分担組 織が 58\% (38 校), プロセス分担組織は大規模大学・中規模病院有・ 中規模病院無の比較的大きな大学のみに見られ 20\%（13 校）であっ た。その他組織 14\%（9 校）のうち，8 校には維持保全担当組織が 設置され，複合組織 8\%（5 校）と合わせて回答機関全体の 40\%（26 校）に維持保全担当部署が設置されている。

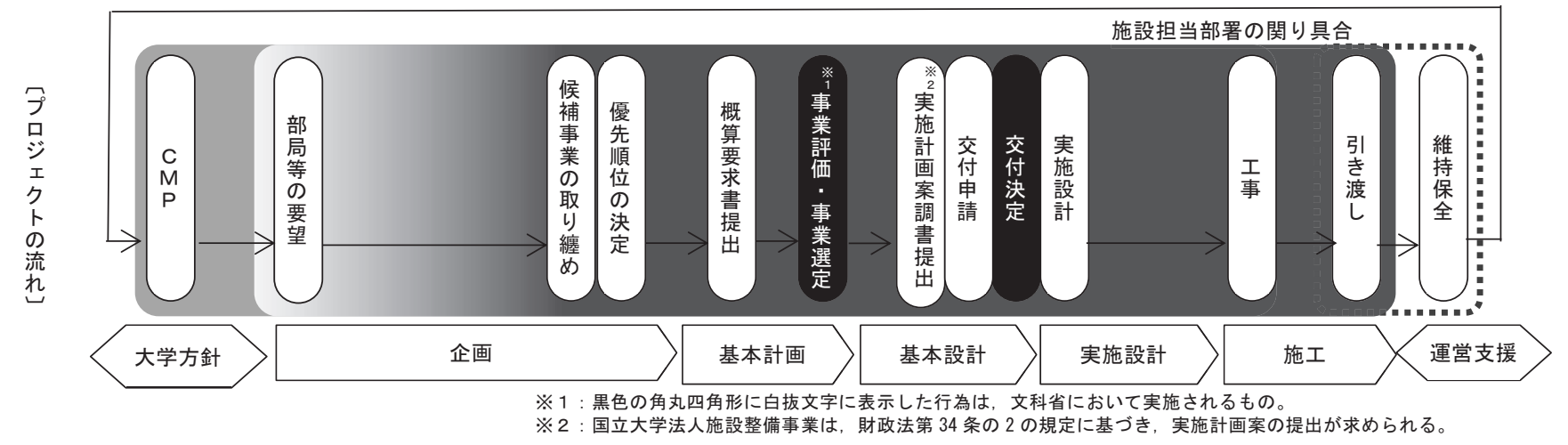

図 1 施設整備プロジェクトの流れ

表 1 アンケート調査の概要

\begin{tabular}{|c|c|c|}
\hline 対象者 & \multicolumn{2}{|c|}{ 国立大学法人 86 機関の施設部署 } \\
\hline 時 期 & \multicolumn{2}{|c|}{$\mathrm{H} 25$ 年 10 月電話及び電子メールで依頼, 提出 12 月 } \\
\hline \multirow[b]{2}{*}{ 内 容 } & 全体に関わる内容 & 個別プロジェクトに関わる内容 \\
\hline & $\begin{array}{l}\text { ·環境配慮に対する取縕 } \\
\text { ·施設部署の組織形態 }\end{array}$ & $\begin{array}{l}\text { ·対象改修プロジェクトの概要 } \\
\text { ·設計の検討状況 } \\
\text { ·空調システムの選定状況 }\end{array}$ \\
\hline 回答数 & 65 校（回収率 75. 6\%） & 57 校（回収率 $66.3 \%$ ） \\
\hline 回答法 & \multicolumn{2}{|c|}{$\begin{array}{l}\text { ·原則, 選択回答 } \\
\text { ·個別プロジェクの面積，工事費 ( } \mathrm{m}^{2} \text { たり千円), 年間エネル } \\
\text { ギー消費量は直接入カ } \\
\text { ·補足で, 自由記述を併用 }\end{array}$} \\
\hline
\end{tabular}

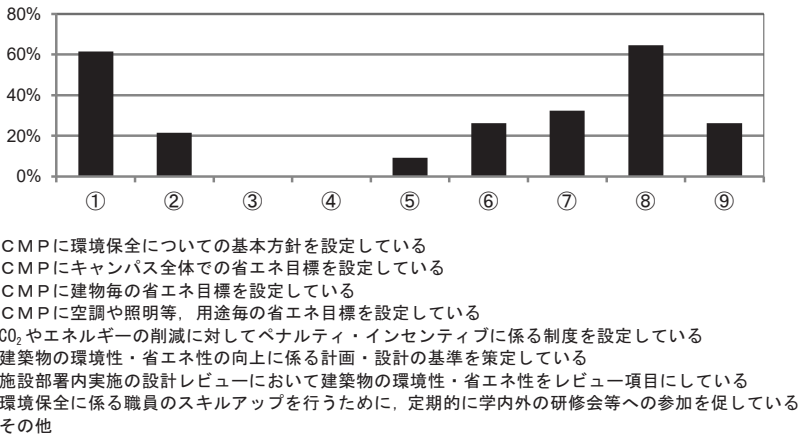

図 2 環境配慮に対する取組（複数回答） 
教員支援タイプは, キャンパス計画室が大規模大学のみ, アドバ イザー教員が中規模病院有・中規模病院無に見られた。これらは, 組織的にある程度余裕があることに起因していると考えられる。

\section{3-4 対象改修プロジェクトの概要}

対象改修プロジェクトは, 概ね $3,000 \mathrm{~m}^{2}$ 以上の校舎とし, 面積, 工事費, 年間エネルギー消費量, 設計外注の分離一括の別の回答を 求め, 表 3 のとおり回答を得た。なお, 校舎は, 講義・研究・実験 の単独と組合せを選択させた。また, サンプルが揃わないので, 他 用途，小規模なものも含めた。設計外注は， 7 割強が建築と設備に 事務所を分けていた。当該施設の年間エネルギー消費量を把握でき るようにしている大学は，9校（16\%）であった。

3ー5 設計時における省エネに関する検討状況

表 2 施設部署と教員支援のタイプ

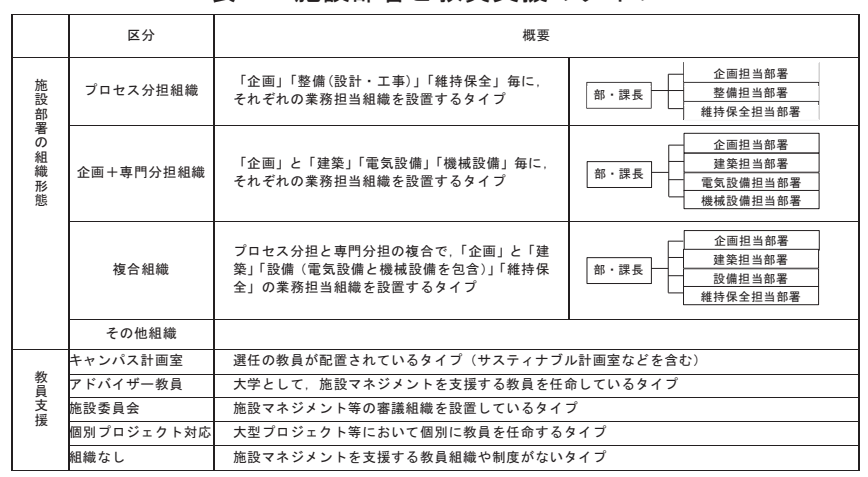

表 3 対象改修プロジェクトの概要

\begin{tabular}{|c|c|c|c|c|c|c|c|}
\hline \multirow{2}{*}{\multicolumn{2}{|c|}{ 用途 }} & \multirow{2}{*}{ 数 } & \multirow{2}{*}{$\begin{array}{c}\text { 面栍 } \\
\text { (平均) }\end{array}$} & \multicolumn{4}{|c|}{ 工事費（m²たたり千円） } \\
\hline & & & & 建築 & 電気 & 機械 & 計 \\
\hline \multirow{6}{*}{$\begin{array}{l}\text { 校 } \\
\text { 垃 }\end{array}$} & 講義 & 4 & $3,300 \mathrm{~m}^{2}$ & 77.9 & 14.8 & 34.4 & 127.1 \\
\hline & 研究 & 4 & $3,347 \mathrm{~m}^{2}$ & 67.7 & 26.8 & 33.6 & 128.1 \\
\hline & 講義+研究 & 4 & $5,002 \mathrm{~m}^{2}$ & 95.8 & 30.5 & 34.3 & 160.6 \\
\hline & 講義＋実験 & 2 & $3,428 \mathrm{~m}^{2}$ & 56.9 & 18.8 & 40.0 & 115.7 \\
\hline & 実験＋研究 & 15 & $4,323 \mathrm{~m}^{2}$ & 86.4 & 33.7 & 61.9 & 182.0 \\
\hline & 講義＋実験＋研究 & 22 & $4,251 \mathrm{~m}^{2}$ & 67.4 & 20.1 & 32.5 & 120.0 \\
\hline \multirow{4}{*}{$\begin{array}{l}z \\
\text { の } \\
\text { 他 }\end{array}$} & 病院 & 1 & $29,790 \mathrm{~m}^{2}$ & 89.7 & 34.1 & 69.9 & 193.7 \\
\hline & 事務局棟 & 2 & $1,807 \mathrm{~m}^{2}$ & 42.5 & 29.5 & 28.0 & 100.0 \\
\hline & 福利施設 & 2 & $2,769 \mathrm{~m}^{2}$ & 85.5 & 40.0 & 44.0 & 169.5 \\
\hline & 医学系図書館 & 1 & $3,242 \mathrm{~m}^{2}$ & 128.0 & 16.0 & 19.0 & 163.0 \\
\hline & 計 & 57 & $4,456 \mathrm{~m}^{2}$ & 78.2 & 26.9 & 42.8 & 147.9 \\
\hline \multicolumn{2}{|r|}{ 設計外注 } & \multicolumn{6}{|c|}{ 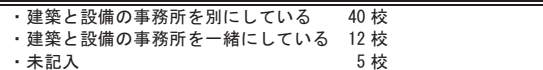 } \\
\hline & 年間エネルギー消費量 & \multicolumn{6}{|c|}{ 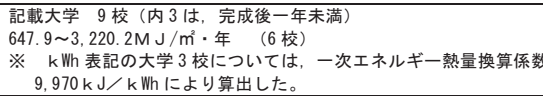 } \\
\hline
\end{tabular}

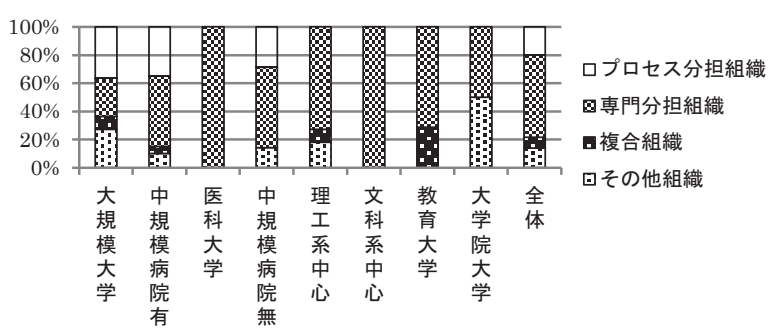

図 3 施設部署の組織形態

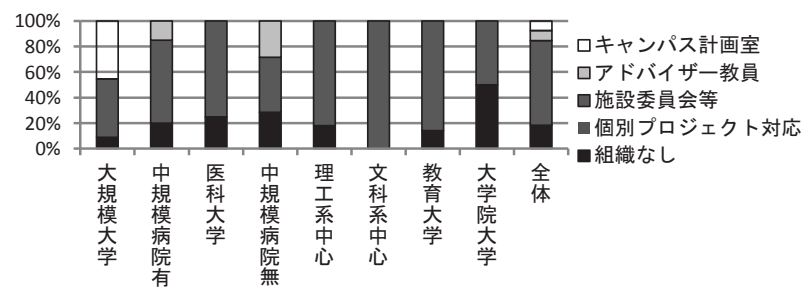

図 4 教員支援体制
設計に係るコンセプト，施設計画等の概略検討と詳細検討を，部 局要望・概算要求・実施計画案・実施設計のどの段階で実施してい るかを選択方式で回答を求め, 図 5 の結果を得た。事業や環境のコ ンセプトの概略検討は, 多くの大学で概算要求と早い段階から行わ れているが，具体的な検討を行う詳細検討は，ほとんどが実施設計 になって行われている。なお，文献 27) では，コンセプトワークの

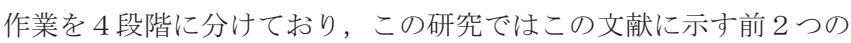
作業を概略検討, あと $2 つ の$ 作業を詳細検討と想定した。他の施設 計画，運営管理，コストスタディなどの詳細検討も，ほとんどが実 施設計になって行われている。設計プロセス初期段階における各種 の詳細な検討が実施設計に入って行われていることが確認できた。

また, コストスタディの詳細検討は, 半数程度しか実施されていな い状況である。

省エネ KPI の検討をしなかった理由は，6つの選択肢〔全学で設 定・必要ない・検討が間に合わない・検討方法が分からない・スキ ルのある職員がいない・職員が不足]から，それぞれ 7 校，3 校，6 校，5校，2 校，3 校の回答があった。また, 自由記述に, 計画手法 の改善提案が 4 校からあり,・実験室等においては過剩な設備を導入 しない,・実験装置の省エネ対策の教員との協働体制の構築, ・空調 設備の選定におけるエネルギー量や運用状況の把握があげられた。

\section{3-6 空調システムの選定状況}

\section{3-6-1 空調システムに係わった者の優先順位}

空調システムの選定に係った者を，(1)運営管理者，(2)施設部署， (3)設計事務所, (4)その他から選択し, 各国立大学法人の施設部署が 優先した順位の回答を求めた。優先順位 1 位は, 施設部署, 運営管 理者，その他（利用者）の順で，その割合は $81 \%, 17 \%, 2 \%$ であ

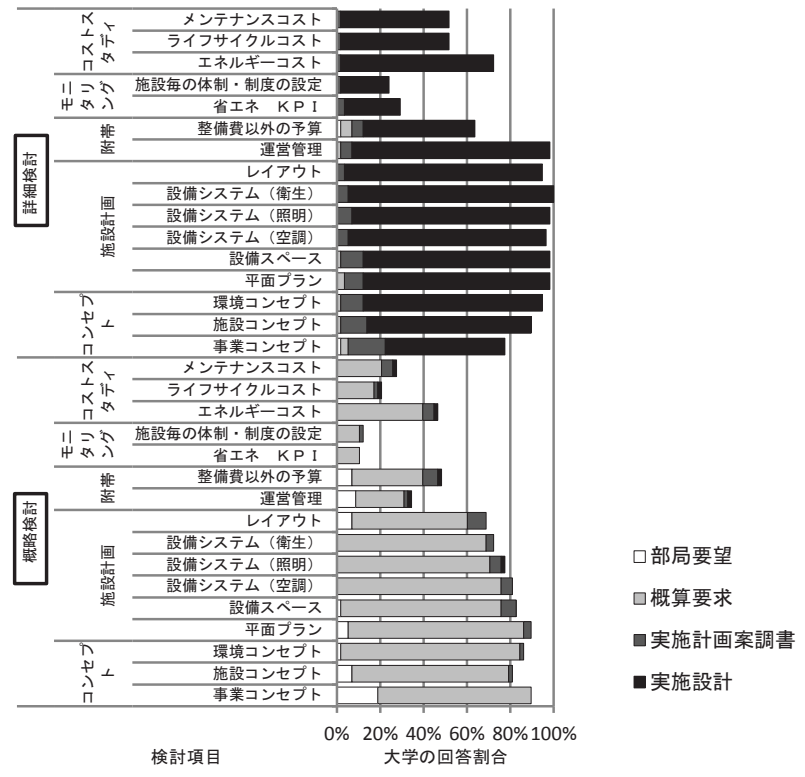

図 5 設計時における省エネに関する検討状況

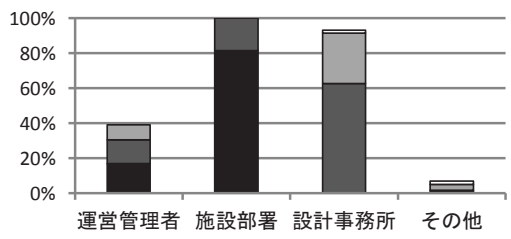

その他 (4 校) - 利用者 3 校

・建築系教員

口4位

口2位

-1位 
った（図 6 )。運営管理者が選定に関わっていない割合が $61 \%$ とい う状況であった。

\section{3-6-2 空調システムの選定に用いた情報}

空調システムの選定に用いた判断情報を, 表 4 から選択し, その 入手時期を概算要求 ・実施計画案調書 - 実施設計の各段階から回答 を求め, 図 7 の結果を得た。この判断情報は, 文献 ${ }^{28)}$ に示されて いる熱源方式の比較検討の項目 (経済性, 運転性能, 信頼性, 省工 ネルギー, 地球環境負荷低減, 建築計画一の影響) に基づき, 国立 大学法人の施設担当部課長へのヒアリングから, 抽出した。

概算要求段階で用いた情報は，(10利用エネルギー，(1)イニシャル コスト，(6)運転管理，(2)ランニングコストの順で，回答割合は順に 44\%，34\%，24\%，22\%であった。全体を通しては, (1)イニシャル コスト，(2)ランニングコスト，(3)利用エネルギー，(14)建築的対応性 の順で，92\%，86\%，80\%，76\%であった。早い段階に検討しなけ ればならない，10利用エネルギーは，44\%が概算要求段階に入手し ているが， 2 割が検討していない。運用時の $\mathrm{CO}_{2}$ 排出量を概算要求 段階に入手しているのは $19 \%$ と, ライフサイクル $\mathrm{CO}_{2}$ と比べて割合 が高いのは, 各大学が概算要求の事業評価の資料として提出してい ることからと推測される。

\section{3-6-3 空調システムの選定に必要な情報}

空調システムの選定において, 省エネ性を更に推進するために必 要と思うものを表 4 に示す判断情報から 3 項目を選択することを求 め, 図 8 の結果を得た。(2)ランニングコスト (56\%), (4)エネルギー 効率 $(52 \%)$, (10利用エネルギー $(32 \%)$ の順であった。3-6-2 と比較寸ると, (14)建築的対応性 (0\%), (5)快適性 (5\%), (6)運転管 理 $(5 \%)$ についての回答割合が大幅に減っており, (1)イニシャルコ スト, (3)維持保全コスト (18\%), (8)保全性 (13\%) 9)耐用年数 (8\%) についての回答割合が半減となっている。

\section{3-7 空調システム選定のための要件整理}

前節で，空調システムの選定情報を整理したが，半数（7つ）の 情報について, 用いられているものと, 必要に思うものに大きな開 きがあることから, 情報の整理が必要と判断し, 省エネルギー計画 の手順から省エネ手法を整理した文献 ${ }^{29)}$ を参考に, 表 5 のとおり整 理した。この表には, 技術的基準である国立大学等施設設計指針 ${ }^{18)}$, 官庁施設の環境保全性基準 ${ }^{19)}$ の省エネ手法を示した。また, 電気 設備に関わることも記載した。現在, 改修プロジェクトにおいては, 断熱材, 複層ガラス, 高効率照明が, 大部分採用されている。これ に, あわせて更に省エネルギー化を進めるには, 表 5 に記載した「1 室内環境条件の適正化」,「(3)自然エネルギーの活用」,「(6)省エネル ギー管理の徹底」に係る検討を確実に実施する必要がある。

\section{3-8 課題と検討項目}

本章のアンケートの実態調査により明らかになった課題から, 省 エネ改修プロジェクトを推進するための検討項目を整理した(表 6 )。

\section{4. 大学への聞き取り調査}

\section{4-1 聞き取り大学の選定}

省エネ対策を他大学に比べて推進している大学を 3 章の実態調査 から, 表 7 のとおり選定し, 平成 26 年 12 月に聞き取り調査をした。 4-2 工夫点と問題点の抽出

聞き取りを表 6 の検討項目に従い, 工夫点を 129 項目, 問題点を

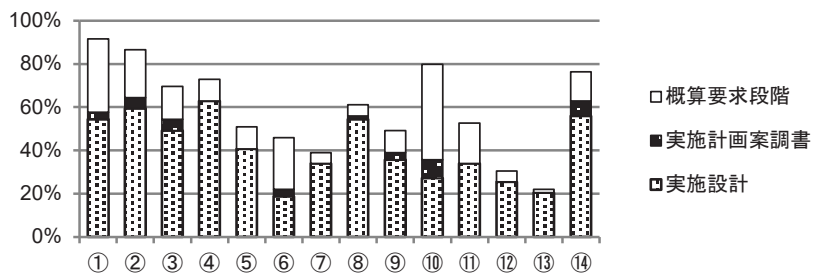

図 7 空調システムの選定に用いた判断情報

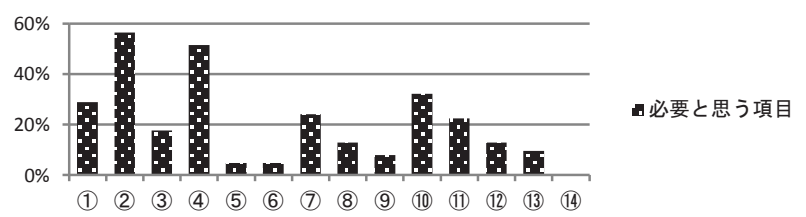

図 8 空調システムの選定に必要な情報

表 4 空調システム選定の判断情報

\begin{tabular}{|c|c|}
\hline 項目名 & 項目名 \\
\hline (1)イニシャルコスト & (8)保全性（点検・清掃·交換） \\
\hline (2)ランニングコスト & (9)耐用年数 \\
\hline （3)維持保全コスト & (10利用エネルギー (電気・ガス・自然) \\
\hline (4)エネルギー効率 & (11)運用時の $\mathrm{CO}_{2}$ 排出量 \\
\hline (5)快適性 & (12)ライフサイクル C O ${ }_{2}$ \\
\hline (6)運転管理 & (13)ライフサイクルエネルギー \\
\hline (7)制御方法（B E M S 等の活用） & (14)建築的対応性 \\
\hline
\end{tabular}

表 5 省エネ手法の整理

\begin{tabular}{|c|c|c|c|}
\hline \multirow{2}{*}{ 要件 } & \multicolumn{3}{|c|}{ 省エネ手法 } \\
\hline & 参考文献 24) & 参考文献 18) & 参考文献 19) \\
\hline $\begin{array}{l}\text { (1)室内環境条件 } \\
\text { 適正化 }\end{array}$ & ·室内温湿度の緩和 & - & - \\
\hline (2)負荷の抑制 & $\begin{array}{l}\text { ·外部負荷の抑制 } \\
\text { · 内部負荷の抑制 } \\
\cdot \text { 外気負荷の抑制 }\end{array}$ & $\begin{array}{l}\text { 外壁の窓等の高断熱化 } \\
\text { ·屋外環境をコントロー } \\
\text { ルすることによる熱 } \\
\text { 負荷の低減 } \\
\end{array}$ & 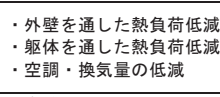 \\
\hline $\begin{array}{l}\text { (3)自然エネルギ } \\
\text { 一の活用 }\end{array}$ & $\begin{array}{l}\cdot \text { 自然通風 } \\
\cdot \text { 外気冷房 } \\
\cdot \text { 太陽エネルギ一利用 }\end{array}$ & $\begin{array}{c}\cdot \text { 太陽光発電設備等の再 } \\
\text { 生エエネ゙利用 }\end{array}$ & $\begin{array}{l}\cdot \text { 自然光の活用 } \\
\text { 自然通風の活用 } \\
\cdot \text { 外気冷房 } \\
\end{array}$ \\
\hline $\begin{array}{l}\text { (4)エネルギーの } \\
\text { 有効活用 }\end{array}$ & 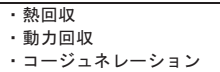 & - & $\begin{array}{l}\text { ·電力負荷の低隇と平隻化 } \\
\text { ·搬送エネルキの政小化 }\end{array}$ \\
\hline $\begin{array}{l}\text { (5)高効率設備の } \\
\text { 採用 }\end{array}$ & $\begin{array}{l}\text { ·高効率システム・機器の } \\
\text { 採用 }\end{array}$ & $\begin{array}{l}\text { ·照明・空調設備の高効 } \\
\text { 率化 }\end{array}$ & $\begin{array}{l}\text { ·効率的な設備システム } \\
\text { 高効率照明器具 } \\
\end{array}$ \\
\hline $\begin{array}{l}\text { 66省エネルギー } \\
\text { 管理の徹底 }\end{array}$ & $\begin{array}{l}\cdot \text { BEMS } \\
\cdot \text { 過冷·加熱の防止 } \\
\cdot \text { 除湿再熱の防止 } \\
\cdot \text { 過剩外気導入の防止 }\end{array}$ & $\begin{array}{l}\cdot \text { - BEMS 導入等による効率 } \\
\text { 的なエネル゙ー管理 } \\
\cdot \text { エネルギー使用料の見 } \\
\text { える化 }\end{array}$ & $\begin{array}{l}\text { ·運転管理システム } \\
\text { 施設部位に応じた点灯方 } \\
\text { 式 }\end{array}$ \\
\hline
\end{tabular}
表 6 課題と検討項目

\begin{tabular}{|c|c|c|c|c|c|}
\hline \multicolumn{2}{|c|}{ 検討項目 } & \multicolumn{4}{|c|}{ 課題 } \\
\hline \multicolumn{2}{|c|}{ 現状把握 } & \multicolumn{4}{|c|}{ 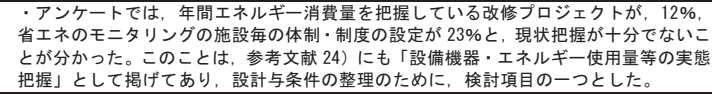 } \\
\hline \multicolumn{2}{|c|}{ 目標設定 } & \multicolumn{4}{|c|}{ 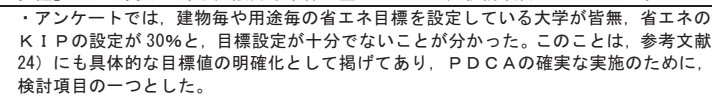 } \\
\hline \multicolumn{2}{|c|}{ 省エネ手法 } & \multicolumn{4}{|c|}{ 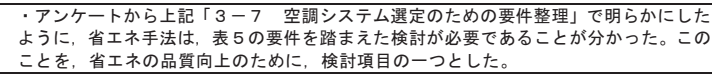 } \\
\hline \multicolumn{2}{|c|}{ 運用改善 } & \multicolumn{4}{|c|}{ 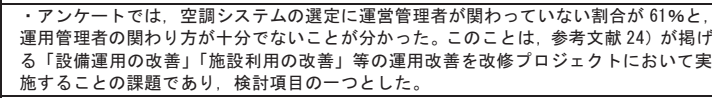 } \\
\hline \multicolumn{2}{|c|}{ プロセス } & \multicolumn{4}{|c|}{ 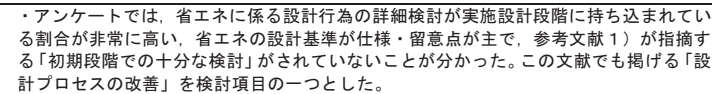 } \\
\hline \multicolumn{2}{|c|}{$\begin{array}{l}\text { コストスタ } \\
\text { ディ }\end{array}$} & \multicolumn{4}{|c|}{ 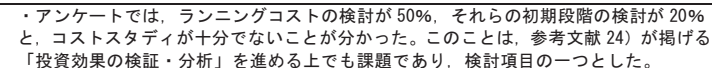 } \\
\hline \multicolumn{2}{|c|}{ 性能検証 } & \multicolumn{4}{|c|}{ 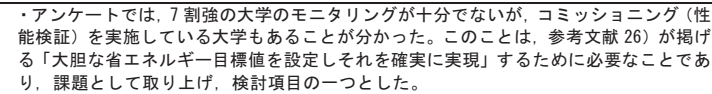 } \\
\hline \multicolumn{2}{|l|}{ 体制 } & \multicolumn{4}{|c|}{ 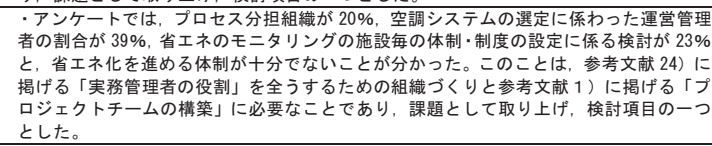 } \\
\hline \multicolumn{6}{|c|}{ 表 7 インタビュー大学の選定 } \\
\hline 記号 & & & \begin{tabular}{|l|l} 
所在地 \\
\end{tabular} & 特色 & \\
\hline & & 院無大学 & 南関東 & 様々な省エネ手法を実現させた改修事例 & 武設備係長 \\
\hline & & 窉院有大学 & 西北陸 & 管理一体型 ESCO の実施大学 & 施設課長他 \\
\hline & & 院有大学 & 東北陸 & 体系的な計画設計基準の策定大学 & 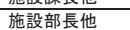 \\
\hline $\mathrm{D}$ & & & 東海 & コミッショニングの実施大学 & 施設課長補佐 \\
\hline $\mathrm{E}$ & & & & $\overline{\mathrm{CO} 2 \text { 削隇を目指す専門組織設置大学 }}$ & \\
\hline
\end{tabular}


173 項目抽出した（表 8 ）。（1）現状把握の「室内環境把握」，（2）目 標設定の「具体的な目標設定」, (4) 運用改善の「実験装置の運用改 善」（5)プロセスの「合意形成」,「企画書」，(6)コストスタディの 「コスト比較」,「財源確保」, (8) 体制の「トップマネジメント」,「役 割・責任」,「モチベーション」は，二律背反の関係にある項目であ る。これは実施できている大規模大学と,これを問題と捉えている, 大規模以外の大学における違いからである。大規模大学は, 施設部 署に組織的に余裕があるからだと考えられる。運用改善は, 参考文 献 21) に掲載された事例を確認できたが，設計どおり運用されてい ない例や，実験装置の集中化・共有化は共同機器センターのような 組織のもとでないと進まないというコメントがあった。集中化・共 有化は組織内で正式な了承を得る場づくりが欠かせないということ である。概算要求時に提出する $\mathrm{CO}_{2}$ 排出削減量等は, 実績データの 収集分析によるものでなく想定した運転時間とカタログ性能等によ る理論值であるので, 運用段階において活用できないと課題を指摘 された。設計外注は，省エネ対策をするには，建築と設備を分ける 方が良いとコメントがあった。

また, 大学内に, 施設整備事業の企画・計画・設計の各々の段階

表 8 エ夫点と問題点の抽出

\begin{tabular}{|c|c|c|c|c|}
\hline 区分 & \multicolumn{2}{|l|}{ 工夫点 } & \multicolumn{2}{|l|}{ 問題点 } \\
\hline \multirow{5}{*}{$\begin{array}{l}(1) \\
\text { 現状把握 }\end{array}$} & ·エネルギー消費分析 & 2 & ・計測データの未活用 & \\
\hline & ·室内環境の把握 & 1 & - 室内環境把握が困難 & 1 \\
\hline & - 教育研究への施設対応状況の把握 & 1 & ·施設対応把握が困難 & 1 \\
\hline & ·省エネ手法採用のための既存調査 & 1 & - 運用 $\cdot$ 運転状況把握が困難 & 2 \\
\hline & ・利用者意識の把握 & 1 & •保有機器データベースの未整備 & 1 \\
\hline \multirow{4}{*}{$\begin{array}{l}\text { (2) } \\
\text { 目標設定 }\end{array}$} & ·省エネ意識の醇成 & 4 & · $\mathrm{CO}_{2} \mathrm{l}_{\|} \|$減の使命感の不足 & 2 \\
\hline & - 具体的な目標設定 & 2 & ·目標設定が困難 & 5 \\
\hline & ·目標管理の徽底 & & ·目標管理が必要 & 3 \\
\hline & & & ·目標設定スキル不足 & \\
\hline & ·各種省エネ対策の採用 & 20 & ・機種選定が不明瞭 (手順，検証等) & 27 \\
\hline \multirow{8}{*}{ 省エネ手法 } & •個別空調の設計基準 & 19 & ·省エネ基準未整備 & 19 \\
\hline & ・照明の省エネ基準 & 4 & ·空調の最大負荷原単位を決めるべき & 19 \\
\hline & - 部屋別省エネ基準 & 4 & ·設計基準のためにデータ蓄積が必要 & 5 \\
\hline & ・省エネ手法選定シミュレーション & 2 & ·省エネ選定シミュレーション未整備 & 5 \\
\hline & •モデル建物 & & ·地域対応基準未整備 & 5 \\
\hline & & & ・省エネ管理仕掛け未整備 & 3 \\
\hline & & & ・学内スキル未活用 & \\
\hline & & & - モデル建物不在 & \\
\hline (4) & ·実験装置の運用改善 & 9 & ・教員との協働体制が不十分 & 1 \\
\hline 運用改善 & ・サーバールームの省エネ設計 & 2 & - 共同利用のルールづくり困難 & 1 \\
\hline \multirow{5}{*}{$\begin{array}{l}\text { (5) } \\
\text { プロセス }\end{array}$} & ·合意形成のエ夫 & 24 & ·合意形成プロセスが不明瞭 & 3 \\
\hline & ·企画書作成 & 1 & ·企画書·基本設計書が未作成 & 3 \\
\hline & - 設計事務所指示書 & & ・初期段階での検討不足 & 6 \\
\hline & & & ・設計プロセスが不明瞭 & \\
\hline & & & ·運用段階への引継ぎ不足 & 5 \\
\hline (6) & 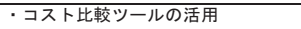 & 4 & ·エネルギーコストの想定が困難 & 2 \\
\hline コスト & ·財源確保の多様化 & 1 & ・省エネ推進予算の不足 & 5 \\
\hline \multirow[t]{2}{*}{ スタディ } & ・コストメリットの共有化 & 1 & ·省エネ水準と整備費の想定困難 & 11 \\
\hline & ・コスト情報の共有化 & & & \\
\hline & - 初期段階性能検証*1 & 4 & 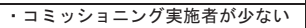 & 3 \\
\hline \multirow[t]{3}{*}{ 性能檢証 } & ・建築設備コミッショニング*2 & 5 & ·実施方法が不明暸 & 3 \\
\hline & ・機能検証を含めたコミッショニング*3 & 1 & ・性能の数値化は困難 & 2 \\
\hline & & & ・管理を部局に任せ放し & 1 \\
\hline (8) & ・トップマネジメント体制 & 3 & ·組織の縦割り構造 & 3 \\
\hline \multirow[t]{3}{*}{ 体制 } & •役割・責任の明確化 & 2 & ・役割・責任が不明確 & 3 \\
\hline & ・スタッフのモチベーション向上 & 1 & ・モチベーション向上が必要 & 1 \\
\hline & & & ·日常業務の軽減 & 4 \\
\hline & 㫮の性能検証は，目標達成 & & 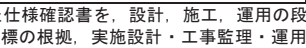 & 階で \\
\hline & & & & \\
\hline $\begin{array}{ll}※ 2: N \\
\varkappa 3\end{array}$ & 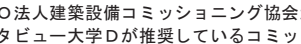 & & グを想定している。 & \\
\hline
\end{tabular}

表 9 学内設計指針としての取組状況

\begin{tabular}{|c|c|}
\hline 大学名 & 取組状況 \\
\hline A 大学 & $\begin{array}{l}\text { ·担当者レベルの引き継ぎメモに, 設計に係る留意事項を記載している。 } \\
\text { ·学内設計指針は組織的余裕がなく策定がでぎったた。 }\end{array}$ \\
\hline B 大学 & 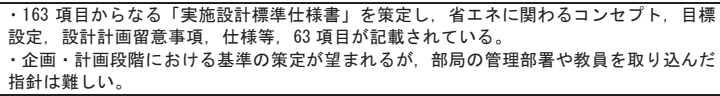 \\
\hline c 大学 & 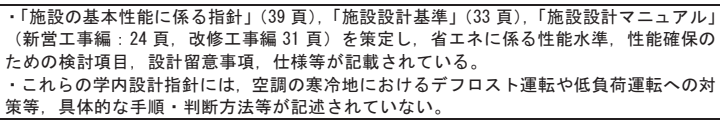 \\
\hline D大学 & ·C 大学と同様な体系的な設計指針に見直し中との回答であった。 \\
\hline E大学 & 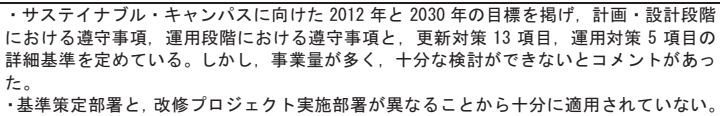 \\
\hline
\end{tabular}

ごとに関係者間の合意形成をし，プロセスを踏まえ内容の深化を図 るという認識が稀薄であることが分かった。これは，平面プランに おいて, スペースの再配分と, 機能強化等への対応検討が遅れ，予 算配賦がされても, 部局や利用教員の中に合意形成や意思決定をし ようという意識が働かず，設備計画・設計が進められないことなど の設計プロセスに係る課題である。

\section{4-3 学内設計指針としての取組}

聞き取り大学における学内設計指針としての取組等を整理した (表 9)。中規模病院無の A 大学では，余裕がなく学内設計指針策 定が難しいこと，他の大学では，学内設計指針が省エネ設計への意 識づけになり省エネ対策が進められていることが確認できた。また, 一部の大学では学内設計指針の運用が的確にされていないことが指 摘され，学内設計指針を運用寸るための仕組みが必要なことが分か った。

\section{4-4. 聞き取り調査のまとめ}

聞き取りから抽出した「工夫点と問題点」と,「学内設計指針とし ての取組」から, 省エネ改修プロジェクトの推進を妨げる阻害要因 と，それを解決するための推進要件を整理した（表 10 ）。

\section{5. まとめ(結論)}

本研究では, 国立大学法人の改修プロジェクトにおける省エネ対 策について, その実態と今後の省エネを進めるための課題が, 下記 のとおり明らかになった。

（1）国立大学法人の施設整備の仕組みにおいて, 省エネに係る技 術的基準類が不明確であることが分かった。

（2）国立大学における改修プロジェクトでは，省エネの目標設定 とモニタリング, 設計プロセス初期段階での検討, 設計一の運営管

\section{表 10 阻害要因と推進要件}

\begin{tabular}{|c|c|c|}
\hline 阻害要因 & 分析結果 & 推進要件 \\
\hline $\begin{array}{l}\text { ·現状がつかめ } \\
\text { ない }\end{array}$ & 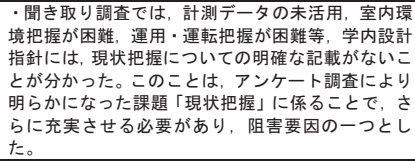 & $\begin{array}{l}\text { ·省エネ手法と運用改善諎討必要な設計情 } \\
\text { 報 (現状) の把握 }\end{array}$ \\
\hline ・意識が希薄 & 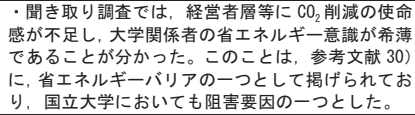 & $\begin{array}{l}\text { ，意思決定, 合意形成, } \\
\text { 達成状況・K K I の公表 } \\
\text { の明確化 }\end{array}$ \\
\hline $\begin{array}{l}\text { ·手法が分から } \\
\text { ない }\end{array}$ & 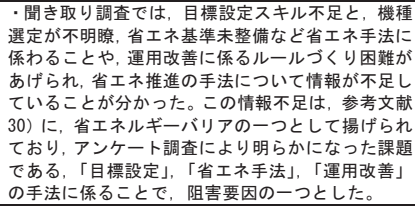 & 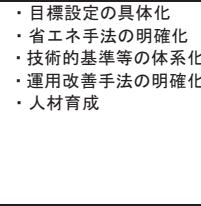 \\
\hline $\begin{array}{l}\text { かプロセスがわ } \\
\text { からない }\end{array}$ & 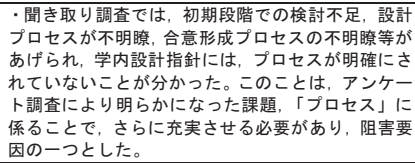 & $\begin{array}{l}\text { 設計プロセスの明確化 } \\
\text { ·設計プロセスの共有化 }\end{array}$ \\
\hline 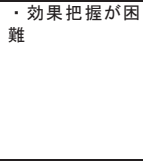 & 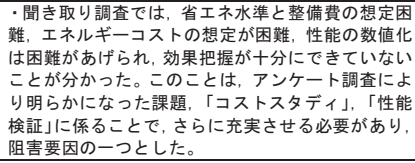 & $\begin{array}{l}\text { ·コストスタディの明哊 } \\
\text { 化 } \\
\cdot \text { 性能検証の明確化 }\end{array}$ \\
\hline $\begin{array}{l}\text { い組織体制がな } \\
\text { い }\end{array}$ & 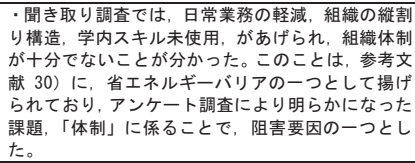 & $\begin{array}{l}\text { ·設計業務の効率化·合 } \\
\text { 理化 } \\
\text { ·縦割り構造の払拭 } \\
\text { 役割・責任の明確化 } \\
\text { ·実験装置等の運用改善 } \\
\text { のための場づくり }\end{array}$ \\
\hline
\end{tabular}


理者の参加, 省エネ手法の検討などが十分でないことが分かった。

（３）国立大学法人の施設部署は, 法人化後, 施設計画・整備・管 理を一元的に担当する体制が求められているが, 維持保全担当部署 を設置している大学が 4 割, 省エネに係るモニタリングの詳細検討 をしている大学が 3 割弱であった。管理業務について, 多くの大学 で十分に実施されていないことが分かった。

（4）省エネ対策を積極的に推進している大学への聞取りの整理か ら, 省エネ改修プロジェクトの推進のための, 検討項目, 阻害要因, 推進要件をあきらかにできた。更に, 国立大学法人の改修プロジェ クトにおいて省エネ対策を確実に推進するには, 学内設計指針が必 要なことが分かった。

今後は, 省エネを推進する設計プロセスをマネジメントしてゆく ために, 学内設計指針の具体的な内容と, これの的確な運用を担保 する仕組みの検討をす寸めてゆく。

\section{謝辞}

本研究においては, 宇都宮大学工学研究科修了者の田代翼氏, 寺 島徹氏や, 花島輝文氏に多大な協力を頂いたことと, 各国立大学施 設部署の職員をはじめ関係各位にアンケートやインタビューに快く 応じて頂いたことに, 深く感謝の意をここに示す。

\section{注}

注 1 ) 参考文献 2 ）では, 部局等の名称から判断し「文科系」「理・農学系」 「工学系」「医学系」「附属病院」の 5 つの系統別に区分したものを「学 問系統」と称している。

注 2 ) 国立大学等は, 国立大学法人, 大学共同利用機関法人, 独立行政法人 国立高等専門学校機構を指す。本研究の対象は国立大学法人である。

注 3 ) 参考文献 10）では, 教育研究の活性化を引き起こすため, 施設計画・ 設計上の工夫を行って, 新たな施設機能の創出を図る創造的な改修を「リ ノベーション」と呼称して，その実施が重要であるとしている。

注 4 ）参考文献 14）では, 戦略的な施設マネジメントの方策に, 省エネルギ 一対策の積極的な推進も掲げ，これらの管理体制の構築を求めている。

注 5 ) 統一基準とは, 国家機関による営綁事務の一層の合理化・効率化のた め, 各府省庁の使用する基準類を統一化したもの。この統一基準は, 各 府省庁及び統一基準決定後に各府省庁から公社・独立行政法人等に移行 した組織においても使用することになっている。

注 6 ) 環境配慮に対する取組についての各選択肢は, 以下のように想定した。

・選択肢(1)〜(4)については, 参考文献 24）の「トップマネジメントによる明 確な方針・目標を策定」「省エネルギー対策の必要性を学内の共通認識 として位置づけ」や参考文献 18）の「省エネルギーの推進のために, 施設の用途を 考慮しつつ環境性能の目標を設定」から，CMPに方針・ 目標を設定することを想定した。

・選択肢(5については，参考文献 25）の「省エネルギーのインセンティブを 与える仕組みの構築」から，想定した。

・選択肢(6)については, 参考文献 5 ) では, 「大学施設において独自に学内 基準を定めること」で「環境負荷削隇に向けた計画・設計が可能となる」 としていることから，想定した。

・選択肢(7については, 参考文献 26) では, 性能検証の一環として「設計レ ビュー」を位置づけていることから，想定した。

- 選択肢8 8 にいては, 参考文献 1 ) では, 国立大学等に求められる取組と して人材育成のために, 定期的な研修会等の開催が必要としていること から, 想定した。

注 7 ) 管理一体型 E S C Oは, 既存施設の管理を含めた E S C O 事業の呼称。

注 8 ) この 8 分類は, 国立大学法人評価委員会国立大学法人分科会業務及び 財務等審議専門部会が平成 17 年 6 月 22 日示した国立大学法人の類型化 (資料 2-3) に，その後の大学の統廃合を反映させたもの。

注 9 ) 財政構造の類型は, 国立大学法人評価委員会国立大学法人分科会業務 及び財務等審議専門部会が, 財務規模, 収支構造への影響と, これらの

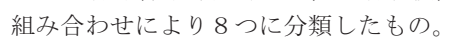

\section{参考文献}

1 ）文部科学省（国立大学等施設の設計に関する検討会）：国立大学等施設 の設計に関する検討会報告書, 2014.3

2 ) 文部科学省（国立大学法人等のエネルギーベンチマーキング手法検討 会）：大学のエネルギーベンチマーキング手法, 2011.3

3 ) 文部科学省大臣官房文教施設企画部 : 大学等における実験・研究に関す る省エネルギー実証事業報告書, 2013.3

4) 文部科学省 : 国立大学法人等施設実態報告書平成 27 年度, 2015.8

5 ) 河野 匡志, 柳原 隆司, 花木 啓祐, 磯部 雅彦, 坂本 雄三: 国立大学施 設における環境負荷低減手法に関する研究, 日本建築学会環境系論文集, 第 76 巻, 第 666 号, pp. 727-734, 2011.8

6 ）李 演生, 赤司 泰義, 渡辺 俊行 他, 福田 健一, 江島 伊佐朗 : 省エネ ルギー手法による空調用エネルギー消費原単位の削減効果と P A L ・ C E C/A C 評価, 日本建築学会計画計論文集, 第 564 号, pp. 55-62, 2003.2

7) 大橋巧, 下田吉之; 理科系研究施設におけるエネルギー消費内訳の推計, 日本建築学会環境系論文集, 第 79 巻, 第 699 号, pp. 443-450, 2014. 5

8 ) 北尾 靖雅, 宗本順三:マスターアーキテクト方式による建築物の集合形 態生成の研究, 日本建築学会計画系論文集, 第 522 号, pp. 215-221，1999.08

9 ）水川尚彦, 古阪 秀三, 金多隆 他, 藤本 真一: 事業用建物の発注者業 務に関する研究, 日本建築学会計画系論文集, 第 605 号, pp. 167-173, 2006. 07

10) 第 4 次国立大学法人等施設整備 5 分年計画, 文部科学大臣決定, 2016.3.29 11) 第 3 次国立大学法人等施設整備 5 力年計画 (平成 23 年度 27 年度) フォ ローアップ[平成 26 年度版] (参照 2015.9.10), http://www. mext. go. jp/ a_ menu/shisetu/kokuritu/_icsFiles/afieldfile/2015/09/15/1326731_4.p $\mathrm{df}$

12）文科省大臣官房文教施設部計画課整備計画室：戦略的なキャンパスマス タープランづくりの手引き， 2010

13）文科省大臣官房文教施設企画部：平成 29 年度国立大学法人等施設整備 費等要求書・同関係資料作成要領, 2016

14) 今後の国立大学等の施設管理に関する調查研究協力者会議：「知の拠点」 を目指した大学の施設マネジメントー国立大学法人（仮称）における施設 マネジメントの在り方について一, 文科省大臣官房文教施設部, 2002

15）東京大学大学院教育学研究科 大学経営・政策研究センター：大学事務 組織の現状と将来 全国大学事務職員調查 報告書, 2010

16）中央教育審議会大学分科会 : 大学のガバナンス改革の推進について(審議 まとめ), 2014.2.12

17）文部科学省の技術的基準一覧：設計関連（参照 2016.5.13） http://www. mext. go. jp/a_menu/shisetu/eizen/04032202. htm

18）文科省大臣官房文教施設企画部：国立大学等施設設計指針，2014

19）国土交通省大臣官房官庁営繥部：官庁施設の環境保全性基準，2014

20）文部科学省大臣官房文教施設企画部 :

大学等における省エネルギー対策の手引き及び事例集（参照 2016.5.13） http://www. mext. go. jp/a_menu/shisetu/green/1292005. htm

21）文部科学省大臣官房文教施設企画部：大学等における省エネルギー対策 事例集＼cjkstart業務用機器（実験装置）編，2012

22）国立大学法人等施設整備に関する検討会について：

平成 13 年 8 月 22 日文教施設部長決定 (参照 2016. 5. 13), http://www. mext. go. jp/b_menu/shingi/chousa/shisetu/037/gaiyou/1358117. htm

23）国立大学法人等施設整備に関する検討会 : 平成 29 年度国立大学法人等 施設整備の方向性, (参照 2016.5.13), http://www. mext.go. jp/b_menu/ shingi/chousa/shisetu/037/toushin/__icsFiles/afieldfile/2015/05/25 /1358121_01.pdf

24）文部科学省大臣官房文教施設企画部：大学等における省エネルギー対策 の手引き一経営層, 実務管理者に向けて一, 2010.3

25）文部科学省大臣官房文教施設企画部：大学等における実験・研究に関す る省エネルギー実証事業報告書，2013.3

26）萱野貴大, 太幡 英亮, 中原 信生, 谷口 元, 恒川 和久: ライフサイクルビ ルコミッショニングの大学施設での実践, その 2 - 建築計画の視点から, 建 築コミッショニングの実践, 日本建築学会大会学術梗概集, 建築社会シス テム, pp. 151-152, 2012.9

27）日本建築学会編：建築企画事典，彰国社 2000. 11

28）建築環境技術研究会 : 建築環境エンジニアリング 4 空調・衛生設備計 画, 鹿島出版会 2000.7

29）井上 宇市：空気調和ハンドブック，丸善，2008

30）省エネ行動とエネルギー管理に関する研究会 : 省エネ行動とエネルギー 管理に関する研究会取りまとめ, 2011.8 


\title{
STUDY ON PROMOTING ENERGY SAVING RENOVATION PROJECTS IN THE NATIONAL UNIVERSITIES
}

\section{Tatsuo FUJIMURA* and Noriyoshi YOKOO**}

\author{
* Grad. Stud., Graduate School of Engineering, Utsunomiya Univ. \\ ** Assoc. Prof., Graduate School of Engineering, Utsunomiya Univ., Ph.D.
}

The national university is requested to implement the measures to realize a low carbon society through life cycle of buildings.

The design period of planning and preliminary design is short, and the detailed design work start without sufficient consideration on energy saving measures. It is expected to improve design process and energy saving measures, which take into account the operation phase, for the facility users do not perceive that the experimental equipment are energy saving objects.

The national universities hold 8,460,000 $\mathrm{m} 2$ buildings that passed more than 25 years and being needed to implement renovation, and it increases by $600,000 \mathrm{~m} 2$ a year. The purpose of this study is that grasp the actual design process and to clarify the promoting measures for carrying out energy saving in the national universities.

The study covers following contents;

(1) Clarify current condition of energy saving measures by investigating the organization of facility planning in the national university.

(2) Clarify current condition of renovation project by conducting a questionnaire survey on the facility planning department in the national universities.

(3) The hearing regarding energy saving measures to the universities that promoting energy saving measures, specified devised points and problems, and clarified obstructive factors and requirement of energy saving promotion.

This study concludes followings;

(1) It is not taken into account following issues; target setting, monitoring, consideration on energy saving at early design stage, participation of facility operators and consideration of energy saving measures.

(2) The ratio of establishment of maintenance division is $40 \%$, implemention of energy monitoring is $30 \%$. It shows that establishment of the management work is not enough in the national universities after turned into national university corporation.

(3) Creating a design guideline regarding to energy saving is one of the factor enhancing energy saving measures at the renovation projects in the national universities based on clarifying consideration items, obstructive factors and requirement of energy saving promotion.

The further study is being intended and it will cover that detailed content of design guideline and a management system which apply the design guideline in the design process appropriately. 